\title{
Naturalized and invasive alien flora of Ghana
}

\author{
Michael Ansong • Jan Pergl (iD) Franz Essl - Martin Hejda - Mark van Kleunen • \\ Rod Randall $\cdot$ Petr Pyšek $(\mathbb{D}$
}

\begin{abstract}
The paper provides an inventory of the naturalized vascular flora of Ghana, based on newly gathered information from the literature and consultations with local experts. We adopted a rather conservative approach by including only species for which strong evidence exists that they are alien in Ghana. We recorded 291 species of naturalized alien plants; for 237 of them there is information on their distribution in the 10 administrative regions of Ghana. Twenty-five
\end{abstract}

\author{
M. Ansong ( $\square)$ \\ Department of Silviculture and Forest Management, \\ Faculty of Renewable Natural Resources, Kwame \\ Nkrumah University of Science and Technology, Kumasi, \\ Ghana \\ e-mail: mansong.canr@knust.edu.gh \\ J. Pergl · M. Hejda · P. Pyšek \\ Department of Invasion Ecology, Institute of Botany, \\ Czech Academy of Sciences, 25243 Průhonice, Czech \\ Republic \\ F. Essl \\ Division of Conservation Biology, Vegetation Ecology \\ and Landscape Ecology, University of Vienna, Rennweg \\ 14, 1030 Vienna, Austria \\ M. van Kleunen \\ Ecology, Department of Biology, University of Konstanz, \\ Universitätsstrasse 10, 78467 Konstanz, Germany
}

species (i.e. $8.6 \%$ of the total number of naturalized species) are classified as invasive. There are 21 widely distributed species ( $7.2 \%$ of the total naturalized flora) that occur in at least eight regions, and five of them are distributed all over the country: Azadirachta indica, Echinochloa colona, Leucaena leucocephala, Senna occidentalis and S. siamea. Of these five, the first three are classified as invasive. The naturalized flora of Ghana includes 71 families, with Leguminosae (66 species), Compositae (22) and Poaceae (18) most represented. The majority of species have their native range in South and North America, contributing 161 and 127 species, respectively. Tropical Asia (98

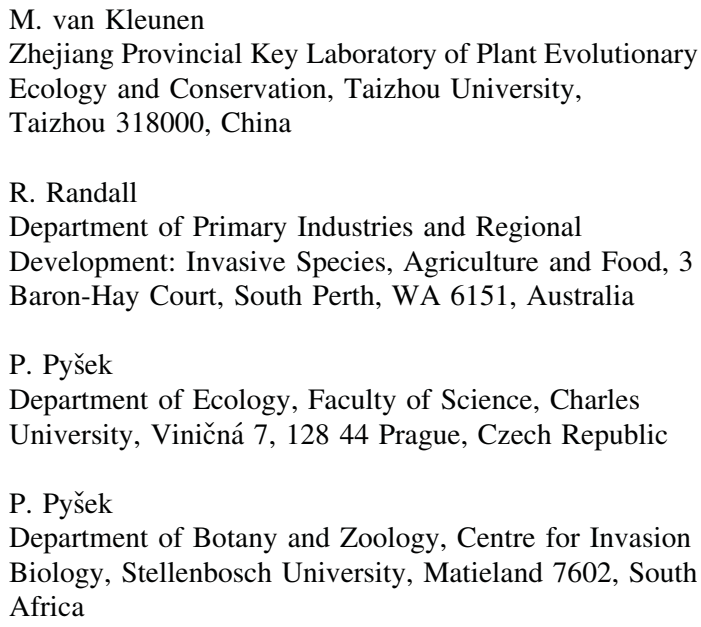


species) and Africa (37 species) are less represented and only three species have their origin in Europe. The dominance of the Americas as a source region is even more pronounced for the subset of invasive species, with this continent accounting for 18 species out of 25 (72\%). Annual and biennial/perennial herbs, shrubs and trees are evenly represented in the naturalized alien species pool. Among invasive species, biennial/perennial herbs are markedly over-represented compared to their contribution to the naturalized flora as a whole ( $52 \%$ vs $38 \%$ ). The same is true for aquatic species (12\% vs $2 \%$ ). Species that occur as naturalized in more than 40 regions in Africa are also more widely distributed within Ghana. The numbers of naturalized species in the administrative regions of Ghana varied from 34 in Upper West to 173 in Greater Accra. These numbers increased with human population density and decreased with distance from the sea, but this pattern was driven by the city of Accra region. The only predictor that remained significant after removing this outlier was the amount of precipitation in the dry period, which was positively associated with the regional richness of naturalized species. This study could serve as a stimulus for other countries in hitherto understudied tropical regions to work towards comprehensive inventories, for which basic data on the alien flora often is still incomplete.

Keywords Africa Climate Exotic plants . Inventory $\cdot$ Life-form · Socioeconomic factors . Tropical regions

\section{Introduction}

We live in a period of rapid human-caused global environmental changes, the Anthropocene (Steffen et al. 2011; Lewis and Maslin 2015). An important component of this new epoch are biological invasions, i.e. intentional or unintentional introductions of alien organisms to parts of the globe where they do not naturally occur (e.g. Vitousek et al. 1997; Richardson 2011; Essl et al. 2018). Although most of those introduced species fail to establish persistent populations in the wild, a significant proportion does, and the numbers are still increasing (Seebens et al. 2017, 2018). Some of those naturalized species are of concern because they have rapidly spread from the foci of introduction and become invasive (Richardson et al. 2000; Blackburn et al. 2011). Among them are species that have negative impacts on the environment or human livelihoods (e.g. Vilà et al. 2011; Pyšek et al. 2012; Blackburn et al. 2014), corresponding to the definition of invasive according to CBD (2000). In recent years, data on the global distribution of naturalized and invasive species of various taxonomic groups have become available (van Kleunen et al. 2015; Dawson et al. 2017; Dyer et al. 2017; Pyšek et al. 2017; Randall 2017; Pagad et al. 2018). A compilation of regional inventories of naturalized vascular plant species, based on the most rigourously applied criteria for evaluating the status of individual species so far, has shown that globally more than 13,000 plant species have now established outside their native ranges (van Kleunen et al. 2015, 2018; Pyšek et al. 2017). Such data are pivotal for addressing major questions in invasion biology (e.g. Razanajatovo et al. 2016; Kalusová et al. 2017), and for riskassessment screening (e.g. Dullinger et al. 2017; Mayer et al. 2017).

Global databases of naturalized and invasive organisms rely on the availability of regional inventories (e.g. Inderjit et al. 2018; Vinogradova et al. 2018). As has been shown for native species, some parts of the world are better researched and have more complete species inventories than others, and many parts of sub-Saharan Africa in particular are known to have rather poor taxonomic coverage (Meyer et al. 2015, 2016). Although the Global Naturalized Alien Flora (GloNAF) database (van Kleunen et al. 2015; Pyšek et al. 2017) includes data for most African countries, the majority of these data come from the African Plant Database (2012), which does not specifically target naturalized species. Those data are thus likely to be incomplete, and therefore more comprehensive inventories of naturalized and invasive plant species are needed for many parts of Africa (van Kleunen et al. 2018).

Here, we contribute to filling this gap by compiling the first inventory of naturalized and invasive vascular plant species for Ghana. We used standard criteria for assigning species as naturalized based on the widely accepted definition by Richardson et al. (2000; see also Pyšek et al. 2004, 2017; Essl et al. 2018). We used this inventory and the distribution of the species in different subregions of Ghana to analyse patterns in the naturalized flora, to describe its structure, and compare it with other regional floras. Finally, we 
identify the geographic and climatic factors that explain variation in naturalized species richness.

\section{Methods}

Study region

Ghana is a tropical country located in the Gulf of Guinea in West Africa. The country covers an area of $238,535 \mathrm{~km}^{2}$, and has an Atlantic coastline that stretches over $560 \mathrm{~km}$. Ghana lies between latitudes $4^{\circ} 45^{\prime} \mathrm{N}$ and $11^{\circ} \mathrm{N}$, and longitudes $1^{\circ} 15^{\prime} \mathrm{E}$ and $3^{\circ} 15^{\prime} \mathrm{W}$. The landscape of Ghana is dominated by flat lowlands and gentle hills, the highest elevation is only $885 \mathrm{~m}$ a.s.l. (Mount Afadjato).

Ghana is divided into 10 administrative regions, which range in size from $3435 \mathrm{~km}^{2}$ (Greater Accra) to $39,557 \mathrm{~km}^{2}$ (Brong-Ahafo) (Table 1). The population of Ghana was 28.8 million people in 2017, with an annual growth rate of $2.2 \%$ (United Nations 2017). The human-population density varies from 35 people/ $\mathrm{km}^{2}$ in the Northern Region to 1236 people $/ \mathrm{km}^{2}$ in Greater Accra (Ghana Statistical Service 2012). Accra, on the eastern part of Ghana's coast, is the capital and most populated city in the country. It is the main hub for imports and exports as it has a large international seaport and airport. The coastal area accounts for $\sim 6 \%$ of the total land area, but has $\sim 30 \%$ of the national population and about $40 \%$ of the urban population. Urban development is concentrated at the coast and is increasing rapidly (Government of Ghana 2015). The climate is tropical with annual average temperatures ranging from 26 to $29{ }^{\circ} \mathrm{C}$. The rain season is longest (April-October) and precipitation is highest in the southern coastal parts of Ghana (up to $2100 \mathrm{~mm}$ annual precipitation). Further north, precipitation declines and in the northernmost regions of the country, the dry season is $\sim 6$ months long. Along the coast, natural vegetation is tropical evergreen rainforest, while most of the country's inlands are naturally dominated by different types of tropical savanna. However, substantial fractions, in particular of the southern and central parts of Ghana, have been converted into agricultural land. The economy of Ghana is dominated by small-scale agriculture, mining, and manufacturing (Government of Ghana 2015). The per capita GDP is 1500 USD (as of 2016), making Ghana one of the most prosperous countries in western Africa. The World Bank currently ranks Ghana's economy in the top of the list of the fastest growing economies in the world (McDonnell 2018).

Ghana's early contacts with Europeans included the Portuguese, Dutch, Danes, Swedes and British in the late fifteenth century and have increased the chances of introduction of alien plant species from Europe and from its overseas colonies into the country. Currently, Ghana provides transit for trade from landlocked countries such as Mali, Burkina Faso and Niger.

Table 1 Naturalized and invasive species richness in the 10 administrative regions of Ghana, with information on human-population size and density, and area

\begin{tabular}{lccccc}
\hline Region & Population size & Area $\left(\mathrm{km}^{2}\right)$ & $\begin{array}{l}\text { Population density } \\
\left(\text { per } \mathrm{km}^{2}\right)\end{array}$ & $\begin{array}{l}\text { Number of } \\
\text { naturalized species }\end{array}$ & $\begin{array}{l}\text { Number of } \\
\text { invasive species }\end{array}$ \\
\hline 1. Ashanti & $4,780,380$ & 24,389 & 196.0 & 104 & 11 \\
2. Brong Ahafo & $2,310,983$ & 39,557 & 58.4 & 91 & 13 \\
3. Central & $2,201,863$ & 9826 & 224.1 & 75 & 7 \\
4. Eastern & $2,633,154$ & 19,323 & 136.3 & 95 & 9 \\
5. Greater Accra & $4,010,054$ & 3245 & 1235.8 & 173 & 17 \\
6. Northern & $2,479,461$ & 70,384 & 35.2 & 87 & 11 \\
7. Upper East & $1,046,545$ & 8842 & 118.4 & 69 & 12 \\
8. Upper West & 702,110 & 18,476 & 38.0 & 34 & 3 \\
9. Volta & $2,118,252$ & 20,570 & 103.0 & 81 & 10 \\
10. Western & $2,376,021$ & 23,921 & 99.3 & 68 & 8 \\
\hline
\end{tabular}


Freight flows total from the country's two sea ports was about 34.3 million tons in 2013. Also, the number of aircraft movements increased by $7.2 \%$ to 23,400 between 2007 and 2013, and the number of passengers by $7.6 \%$ to 1.7 million. On land, the national average daily traffic exceeds one million vehicles per day, with southern areas generally having more traffic than the northern areas (Government of Ghana 2015). All these factors have likely contributed to the intentional and unintentional introductions of alien plants into Ghana.

Data collection

The inventory of vascular alien plant species presented here is based on an extensive review of literature and consultations with local experts. Data was obtained from journal articles, scientific reports, books and book chapters, field guides and manuals, theses, management plans and online database such as GBIF (Supplementary Material 1). Species termed as "alien", "exotic", "foreign", "immigrants", "introduced", "invasive", "naturalized", "non-indigenous", "noxious" and "weeds" were recorded to prepare the initial checklist. Only species reported as growing outside cultivation were included. We adopted a rather conservative approach by including in the list only species for which strong evidence that they are alien in Ghana was available. The first list contained 780 species and was subsequently verified through many internal reviews by colleagues working at the Forest Research Institute of Ghana, Kwame Nkrumah University of Science and Technology, Friends of the Earth, Resource Trust, and Forest Services Department of Ghana. Feedback from these experts was used to develop the final list. Where available, we obtained information on the distribution of the naturalized species in the administrative regions of Ghana.

We classified the alien species according to the stage they reached in the naturalization/invasion process (Richardson and Pyšek 2006) in Ghana. If different stages were reached in different regions, the highest level was assigned (Richardson et al. 2000; Blackburn et al. 2011). Based on this concept, we use the following terms to describe the invasion status: (1) naturalized species (synonym: established species) form self-sustaining populations for several life cycles without direct intervention by people, or despite human intervention; they often recruit offspring freely, usually close to adult plants and their persistence does not depend on ongoing input of propagules; and (2) invasive species are a subset of naturalized species that produce reproductive offspring often in very large numbers at considerable distances from the parents and/or site of introduction, and have the potential to spread over long distances (Richardson et al. 2000).

Species characteristics: life form, year of introduction, global distribution and origin

Data on life forms and global distribution of species as naturalized were extracted from the GloNAF database (version 1.1; van Kleunen et al. 2015; Pyšek et al. 2017) and verified by using online sources and floras. To link the list obtained for Ghana to the GloNAF database, the taxonomy of The Plant List (version 1.1; http://www.theplantlist.org) was used to standardize the original names (i.e. synonyms were completed by accepted scientific names; see van Kleunen et al. 2015) using the $\mathrm{R}$ package Taxonstand (Cayuela et al. 2017). Data on the year of the first record of a species in Ghana were extracted from GBIF (2017), and are originally based on herbarium records.

Alien range size was quantified as the number of GloNAF regions, not including Ghana (a total of 842 regions), where a species is naturalized. As to the life form, species were classified into the following categories: annual herb; perennial herb (including biennials); shrub; tree; climber; and aquatic plant. This information was available for all but 13 species.

Data on the origin of species was extracted from GRIN (https://npgsweb.ars-grin.gov) and then checked by literature and web searches (https://plants. jstor.org, www.issg.org). To classify the region of origin, each species was assigned to one or more of the nine major biogeographically defined areas (continents) of the Taxonomic Databases Working Group (Brummit 2001). Species whose native range is unknown as they are only recorded from cultivation and species that originated through recent humanmediated hybridization are listed as a separate category. 
Region data

The following characteristics were obtained for each of the 10 administrative regions of Ghana: climate, area, human population size and density, distance (centroid of the region) from the coast, and prevailing vegetation (Ghana Statistical Service 2012; Issaka et al. 2012; Government of Ghana 2015). The regions differ in climate and socioeconomic features, which are correlated with the distance from the coast, because the coastal regions are the centers of trade in ports and in cities. To characterize the climate in administrative regions, we used the first three axes of PCA on 19 bioclimatic variables (WorldClim database; Dupin et al. 2011). The resulting PCA axes represent three uncorrelated linear combinations of the original data, with PCA axis 1 related mainly to mean annual temperature, $\mathrm{PCA}$ axis 2 to precipitation during wet or warm periods, and PCA axis 3 to precipitation during dry seasons (see e.g. Inderjit et al. 2018; Vinogradova et al. 2018 for examples of their use for analysing invasion patterns). The vegetation in each region was classified into the following categories: savanna, transitional vegetation (forest-savanna transition), deciduous tropical forest and tropical high-rain forest. If more than one vegetation type occurs within a region, the proportion of the corresponding extent was used (Issaka et al. 2012).

\section{Statistical analysis}

Regression trees (Breiman et al. 1984; De'ath and Fabricius 2000) were used to analyse factors that determine the number of naturalized plant species in a region (naturalized species richness), and the number of Ghana regions where the species is recorded (naturalization extent of individual species); these numbers were used as response variables. For naturalized species richness, climatic PCA scores, distance to coast, vegetation type and population density were explanatory variables. For species' naturalization extent, explanatory variables were life form, continent of origin, and the total number and sum of areas of GloNAF regions in Africa (excluding Ghana) and in the world, from which the species is reported as naturalized (Pyšek et al. 2017). Regression trees were constructed using binary recursive partitioning, with the default Gini index impurity measure used as the splitting index, in CART v. 8.0 (Breiman et al. 1984; Steinberg and Colla 1995).

For factors identified by regression trees as important, Pearson correlations between the number of naturalized species in a region and the corresponding factors were calculated (Crawley 2007). As the Accra region is an outlier with regard to the number of naturalized species, data were analysed once with and once without inclusion of the Accra region. All analyses were done in R 3.0.2 (R Core Development Team 2014).

\section{Results}

Alien species diversity in Ghana: the big picture

In total, we recorded 291 species of naturalized alien plants in Ghana, and for 237 of those there is information on their distribution in the 10 administrative regions. Twenty-five species (i.e. $8.6 \%$ of the total number of naturalized) are classified as invasive, and for 20 of them detailed information is available about their distribution in regions (see Supplementary Material 2 for the complete data set). The first records of species that are nowadays naturalized in Ghana are from the late 1880 s, then there was a period of rather rapid steady increase between the 1930s and 1970s. This period was followed by a slow and decelerating increase lasting until now; only eight newly naturalized alien species have been recorded since 1995 (Fig. 1).

Taxonomic structure of the naturalized alien flora

The frequency distribution of species in the Ghanian regions is shown in Fig. 2. There are 21 widely distributed species ( $7.2 \%$ of the total naturalized flora) that occur in at least eight regions, and five of them are distributed all over the country (i.e. in all 10 regions): Azadirachta indica, Echinochloa colona, Leucaena leucocephala, Senna occidentalis and S. siamea, the first three being classified as invasive. Another invasive species among the widely distributed ones (as listed in Table 2) is Gliricidia sepium, recorded from eight regions. Overall, however, the invasive species are evenly distributed across the classes defined by the numbers of regions rather than concentrated to classes of the most widespread species; 12 of them (48\%) 
Fig. 1 Increase in the cumulative number of naturalized alien species in Ghana based on the first reports from the country
Fig. 2 Frequency distribution of naturalized but non-invasive (empty bar, $\mathrm{n}=266)$ and invasive species (black part of the bar, $\mathrm{n}=25$ ) in 10 regions of Ghana. Note that the invasive status has been assigned for the country as a whole. Species for which there is no information available on their detailed distribution in Ghana are shown in the category 'unknown'
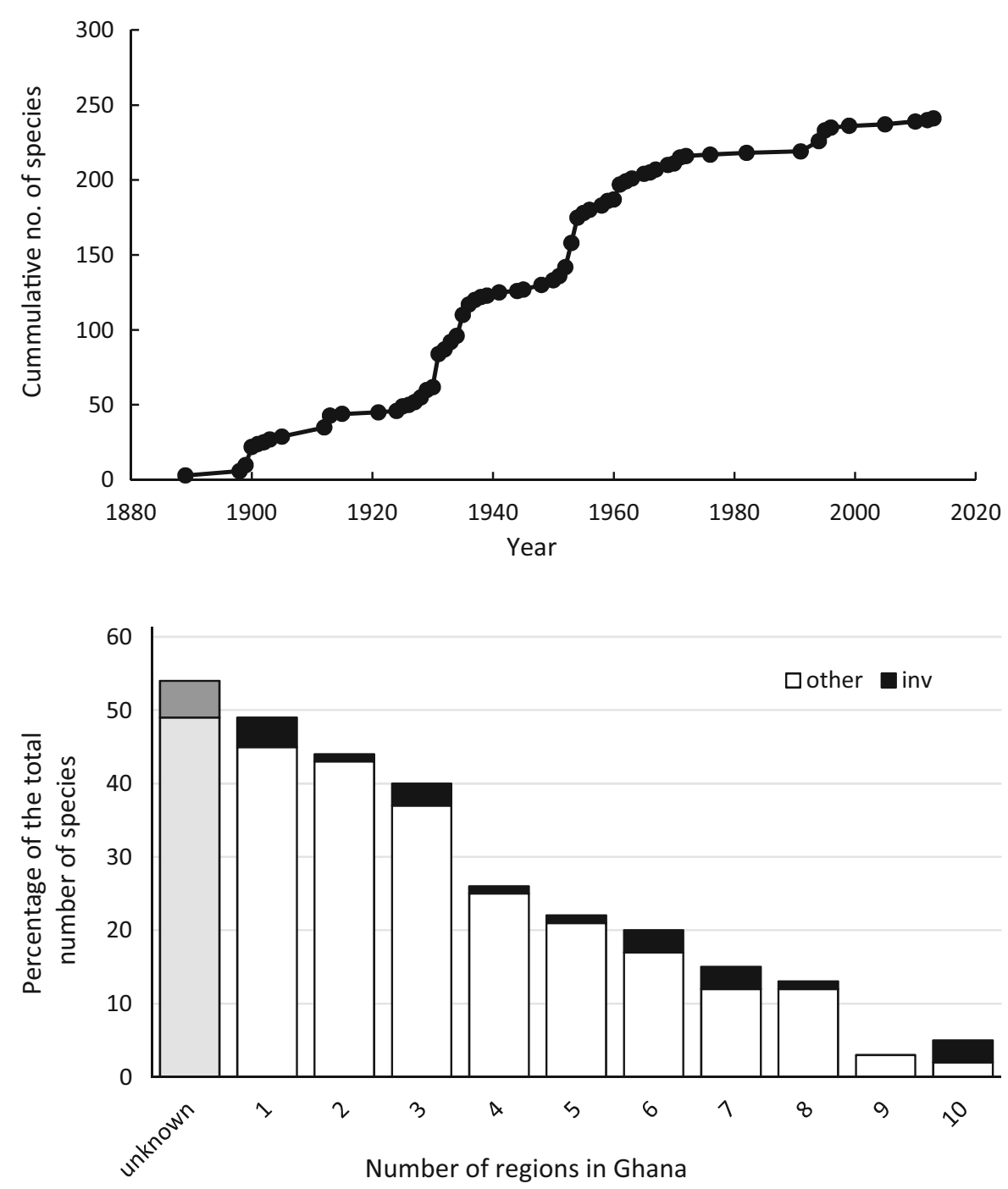

occur in as few as 1-3 regions, and for five invasive species there is no detailed information on their distribution in the Ghana regions.

There are 71 families represented in the naturalized flora of Ghana (Table 3, Supplementary Material 1), with Leguminosae (66 species, i.e. $22.7 \%$ of the total number), Compositae $(22 ; 7.6 \%)$ and Poaceae (18; $6.2 \%$ ) being richest in species. Seven families are represented by at least 10 species and 21 by at least three. The pattern is different when looking at widespread species (i.e. those occurring in eight or more regions) separately, where Leguminosae $(33.3 \%)$ and Poaceae (14.3\%) increased their representation. The pattern is also different when looking at invasive species, among which Leguminosae still prevailed $(24.0 \%)$ but Compositae gained in importance $(16.0 \%)$, compared to their contribution to the total number of non-invasive species (Table 3 ).

\section{Life form and origin}

The vast majority of naturalized alien species in Ghana have their native range in the Americas, with South and North America contributing 161 and 127 species, respectively (representing $55.3 \%$ and $43.6 \%$ of the total of 291 naturalized species in Ghana). Tropical Asia is also highly represented (98 species), but Africa less so (37 species) and the contribution of Europe is negligible (only three species of European origin are recorded: Hibiscus trionum, Nymphoides peltata and 
Table 2 The most widespread taxa in the naturalized alien flora of Ghana; those recorded in at least 8 out of 10 regions are shown, species status is indicated (nat-naturalized, inv-invasive; definitions follow Richardson et al. 2000; Blackburn et al. 2011). Nomenclature follows the Plant List. Life form: ann-anual herb, per-bienial or perennial herb, shr-shrub, tree-tree

\begin{tabular}{lllll}
\hline Species & Family & Life form & No. regions & Status \\
\hline Echinochloa colona & Poaceae & ann & 10 & inv \\
Senna occidentalis & Leguminosae & per, shr & 10 & nat \\
Senna siamea & Leguminosae & tree & 10 & nat \\
Leucaena leucocephala & Leguminosae & shr, tree & 10 & inv \\
Azadirachta indica & Meliaceae & tree & 10 & inv \\
Cajanus cajan & Leguminosae & shr & 9 & nat \\
Dactyloctenium aegyptium & Poaceae & ann, per & 9 & nat \\
Hyptis suaveolens & Lamiaceae & ann, per & 9 & nat \\
Bidens pilosa & Compositae & ann & 8 & nat \\
Centrosema pubescens & Leguminosae & per & 8 & nat \\
Crotalaria retusa & Leguminosae & shr, per & 8 & nat \\
Euphorbia hirta & Euphorbiaceae & ann & 8 & nat \\
Gliricidia sepium & Leguminosae & tree & 8 & inv \\
Heliotropium indicum & Boraginaceae & ann & 8 & nat \\
Hyptis lanceolata & Lamiaceae & shr & 8 & nat \\
Chrysopogon aciculatus & Poaceae & per & 8 & nat \\
Jatropha curcas & Euphorbiaceae & shr, tree & 8 & nat \\
Moringa oleifera & Moringaceae & shr, tree & 8 & nat \\
Physalis angulata & Solanaceae & ann & 8 & nat \\
Scoparia dulcis & Plantaginaceae & ann, per & 8 & nat \\
Sida acuta & Malvaceae & per, shr & 8 & nat \\
\hline & & & &
\end{tabular}

Sonchus oleraceus). The dominance of the Americas as a source region is even more pronounced for the subset of invasive species, with this continent accounting for $72 \%$ (18 species out of 25; Fig. 3a).

In terms of life forms, four categories, i.e. annual herbs, biennial/perennial herbs, shrubs and trees, each contributed $92-107$ species, corresponding to $32-38 \%$ of the total naturalized alien species pool (Fig. 3b). Among invasive species, biennial/perennial herbs are markedly over-represented compared to their contribution to the naturalized flora as a whole $(52.0 \%$ vs $38.0 \%)$. This is also the case for aquatic species $(12.0 \%$ vs $2.4 \%)$. The opposite is true for annual herbs, whose contribution to the invasive flora $(28.0 \%)$ is lower than to the naturalized flora (37.3\%) (Fig. 3).

Factors affecting the naturalization extent in Ghana

A regression tree with life form, continent of native range and the number of GloNAF regions occupied by the species globally and in Africa as explanatory variables, revealed that species' naturalization extent in Ghana was most strongly associated with its naturalization in the rest of Africa. Species that occur as naturalized in more than 40 GloNAF regions in Africa are more widely distributed (on average in $5.7 \pm 2.4$ regions in Ghana, mean $\pm \mathrm{SD}$ ) than those reported from fewer African regions (on average in $3.4 \pm 2.2$ regions in Ghana). The latter group is further differentiated by the sum of geographic areas of world regions where the species has naturalized, with the probability of it being recorded in more Ghanian regions increasing with this area (Fig. 4).

Regional perspective: factors affecting the naturalized species richness

The numbers of naturalized species in the administrative regions of Ghana varied from 34 in Upper West to 173 in Greater Accra (Table 1, Fig. 5). The number of naturalized species in a region increased with human population density (Fig. 6a) and decreased with the distance of the region from the sea (Fig. 6b). Greater Accra represents an outlier both in terms of population density and distance from the sea, and after removing this data point neither the effect of population density 
Table 3 Representation of families among all naturalized species, among those that are widespread (occurring in at least eight of 10 regions) and among species classified as invasive

\begin{tabular}{|c|c|c|c|c|c|c|}
\hline & \multicolumn{2}{|c|}{ Naturalized $(\mathrm{n}=291)$} & \multicolumn{2}{|c|}{ Widespread $(n=21)$} & \multicolumn{2}{|c|}{ Invasive $(\mathrm{n}=25)$} \\
\hline & No. & $\%$ & No. & $\%$ & No. & $\%$ \\
\hline Leguminosae & 66 & 22.7 & 7 & 33.3 & 6 & 24.0 \\
\hline Compositae & 22 & 7.6 & 1 & 4.8 & 4 & 16.0 \\
\hline Poaceae & 18 & 6.2 & 3 & 14.3 & 1 & 4.0 \\
\hline Euphorbiaceae & 14 & 4.8 & 2 & 9.5 & 1 & 4.0 \\
\hline Convolvulaceae & 11 & 3.8 & & & & \\
\hline Amaranthaceae & 10 & 3.4 & & & & \\
\hline Solanaceae & 10 & 3.4 & 1 & 4.8 & & \\
\hline Lamiaceae & 9 & 3.1 & 2 & 9.5 & & \\
\hline Malvaceae & 9 & 3.1 & 1 & 4.8 & & \\
\hline Apocynaceae & 8 & 2.7 & & & & \\
\hline Myrtaceae & 6 & 2.1 & & & & \\
\hline Verbenaceae & 6 & 2.1 & & & 1 & 4.0 \\
\hline Bignoniaceae & 5 & 1.7 & & & & \\
\hline Moraceae & 5 & 1.7 & & & 1 & 4.0 \\
\hline Rubiaceae & 5 & 1.7 & & & & \\
\hline Cucurbitaceae & 4 & 1.4 & & & 1 & 4.0 \\
\hline Phyllanthaceae & 4 & 1.4 & & & & \\
\hline Acanthaceae & 3 & 1.0 & & & & \\
\hline Combretaceae & 3 & 1.0 & & & & \\
\hline Lauraceae & 3 & 1.0 & & & & \\
\hline Meliaceae & 3 & 1.0 & 1 & 4.8 & 2 & 8.0 \\
\hline Oxalidaceae & 3 & 1.0 & & & & \\
\hline
\end{tabular}

nor that of the distance from the sea remained significant.

To test the effect of climate on the naturalized species richness in the Ghana regions, we used the PCA climatic scores, of which only PCA 3, representing precipitation in the dry period, had a significant effect. Regions receiving more precipitation in the dry period harbour more naturalized species, and this relationship remained marginally significant ( $p$ value $=0.0902)$ with the outlier Greater Accra removed (Fig. 7).

\section{Discussion}

The richness of the alien flora of Ghana in a wider context

The 291 naturalized alien species recorded in this paper represent substantial improvement of knowledge about this component of the Ghanian flora, based on rigorous approach to the classification of species status. Previous accounts reported much fewer naturalized taxa for this country, 190 in total (African Plant Database 2012), but also as many as 680 species of weeds regardless of their status (also including native weeds) and character of occurrence (see the list in Randall 2017). About the same proportional increase as in comparison with the African Plant Database (2012) is observed in the number of reported invasive species, with 25 newly classified in this category compared to 16 that were previously classified as such (CABI 2014). Based on the new figures reported here, $8.6 \%$ of the naturalized taxa are invasive, a proportion that is well in accordance with the tens rule of biological invasions (Williamson and Fitter 1996; Jeschke and Pyšek 2018).

The previous numbers of naturalized and invasive plants referred above (African Plant Database 2012; CABI 2014) were also used in global analyses of patterns in plant naturalization (van Kleunen et al. 2015; Pyšek et al. 2017). This points to the value of 

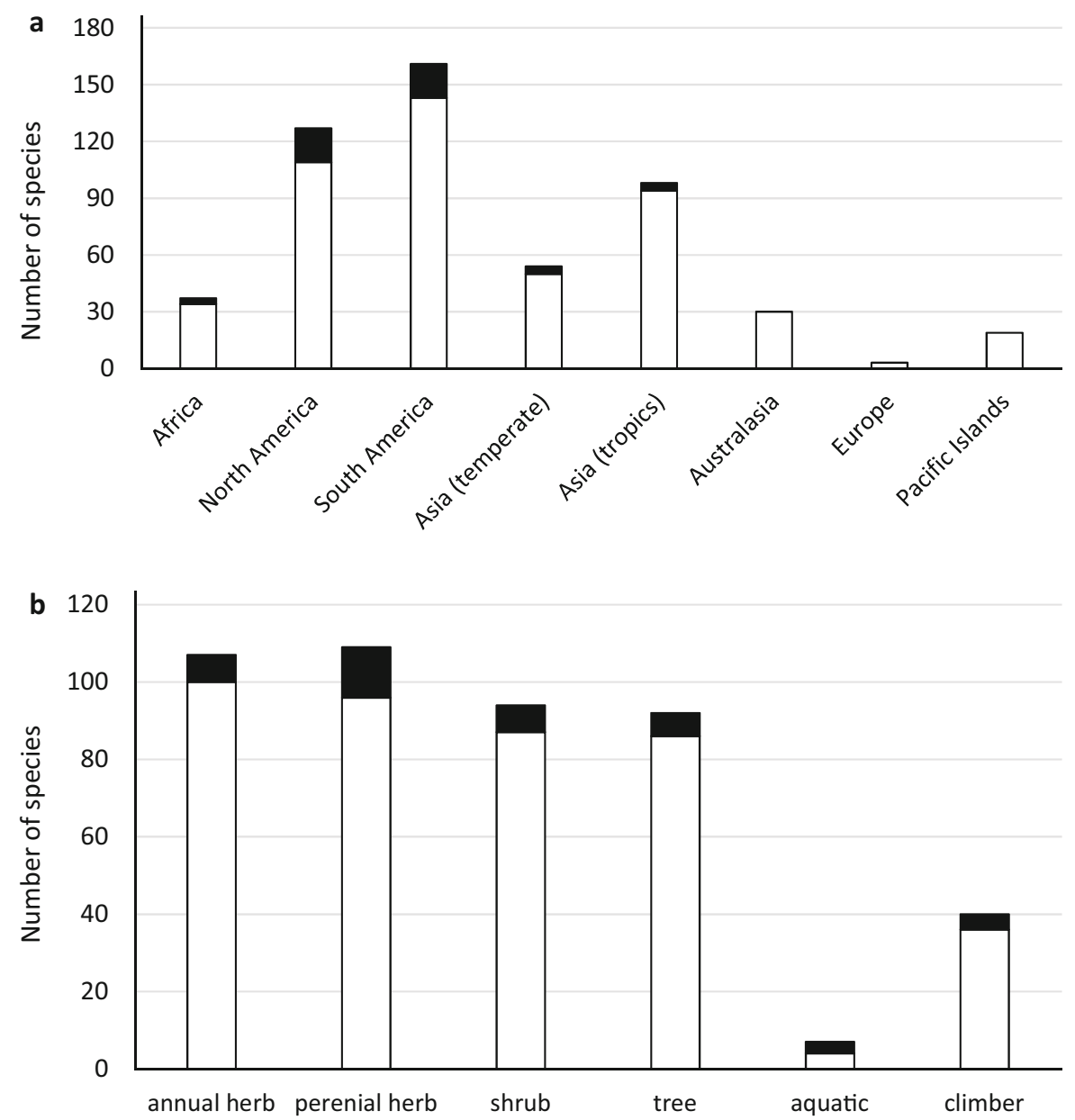

Fig. 3 a Contribution of continents where species that have successfully naturalized in Ghana are native, and $\mathbf{b}$ life form spectra, shown for naturalized non-invasive (white part of the bar) and invasive (black part) alien plants in the flora of Ghana. Note that the total number exceeds the 291 naturalized species recorded in the country because some species originate from more than one continent, or have multiple life forms; in such cases they were assigned to each. The continent delineation follows the Taxonomic Databases Working Group (Brummit 2001)

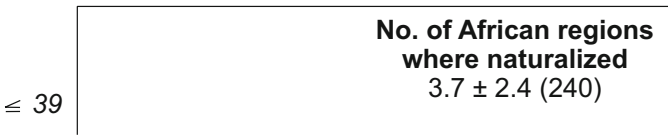

\begin{tabular}{ccc}
$\leq 4975257$ & \multicolumn{3}{c|}{$\begin{array}{c}\text { Area of regions where } \\
\text { occurs globally (km2) }\end{array}>4975257$} \\
Terminal node 1 & $3.4 \pm 2.2(206)$ & Terminal node 2 \\
$2.6 \pm 1.8(59)$ & & $3.7 \pm 2.3(147)$
\end{tabular}

Fig. 4 Regression tree with the number of Ghanian regions where the naturalized alien species present in the country's flora occur as the explained variable. The explanatory variable number of African regions where the species is naturalized was

detailed floristic investigations that make use of local literature including grey sources, and almost always taken from GloNAF (van Kleunen et al. 2015; Pyšek et al. 2017). Each splitting node (splitting variable name and splitting criterion) and each terminal node shows the naturalized species number (mean and SD; number of cases)

yield more reliable results than databases covering large areas of the continents; such regional data are 


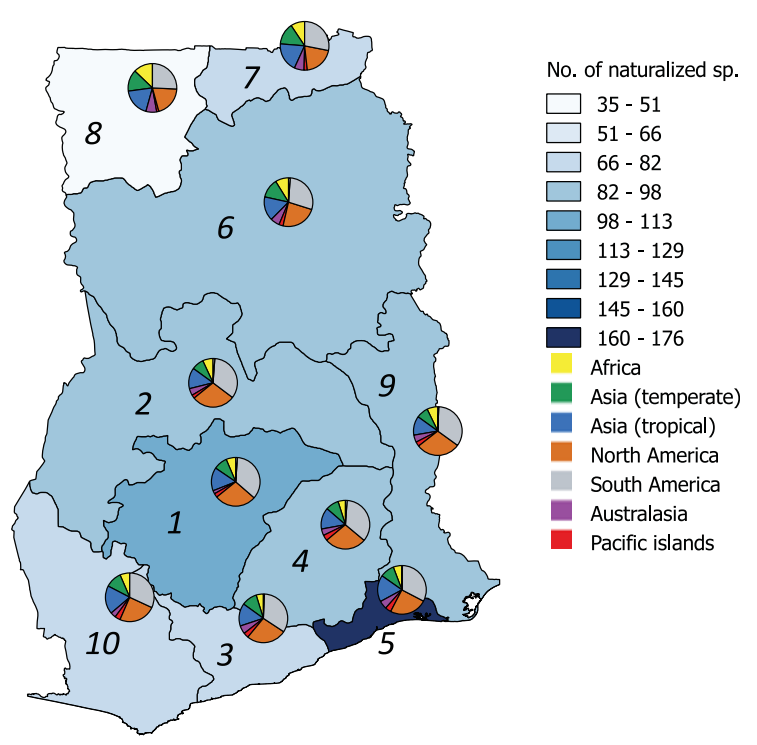

Fig. 5 Naturalized species richness in the 10 administrative regions of Ghana (colour scale) and continent-of-origin spectra of species recorded there (pie charts). Note that Europe is not shown because of its negligible contribution, and the fact that for the few species with European origin the distribution in regions is unknown. The numeric codes of regions correspond to their names in Table 1

thus more suitable for robust analyses of invasions (van Kleunen et al. 2015; Pyšek et al. 2017, 2018). Moreover, if focused research towards compiling as complete and rigorous as possible checklists of naturalized aliens also includes information on their subnational distribution, valuable data on measures of abundance of individual taxa at the country scale can be obtained (e.g. Inderjit et al. 2018; Vinogradova et al. 2018).

The newly recorded number of naturalized species makes Ghana the country with the highest alien plant richness in the West African region, exceeding the numbers reported for the neighbouring countries of similar size, such as Ivory Coast (266 taxa; $\left.319,788 \mathrm{~km}^{2}\right)$ and Burkina Faso (149 taxa; $272,980 \mathrm{~km}^{2}$ ), and of countries of smaller size such as Liberia (141 taxa; $95,176 \mathrm{~km}^{2}$ ) and Togo (63 taxa; $55,956 \mathrm{~km}^{2}$ ). This holds also true when we compare Ghana to the much bigger Nigeria (193 taxa; $909,687 \mathrm{~km}^{2}$ ), which suggests that Nigeria might be under-explored in terms of its alien flora. The only exception of a country in the region richer in naturalized aliens is Benin with 333 taxa per $118,027 \mathrm{~km}^{2}$ (African Plant Database 2012). In terms of economic output of these countries, which is a factor well known to be related to naturalized species richness (e.g. Pyšek et al. 2010), the only one with per capita GDP similar to Ghana (1641 USD) is Nigeria (1968 USD). The other countries have markedly lower per capita GDP, ranging from 456 USD in Liberia to 830 USD in Benin (worldbank.org, data for 2017). The relationship between the number of naturalized species and per capita GDP for the six countries was not significant $(r=0.42, p=0.407)$.

Which factors affect the richness of the alien flora of Ghana?

How widely a species has become naturalized in Ghana was primarily associated with the 'naturalization elsewhere' principle, analogous to the commonly used 'invasive elsewhere' (Reichard and Hamilton 1997; Křivánek and Pyšek 2006; Herron et al. 2007; Dawson et al. 2008; Milbau and Stout 2008). Species that occur as naturalized in more than 40 GloNAF regions in Africa were more widely distributed in Ghana, and the pattern was fine-tuned by the size of the global naturalization range of a species. The latter was also found to be important for naturalization success of ornamental plants in Europe (Haeuser et al. 2018).

The almost complete absence of European species in the Ghanian alien flora is remarkable, even more so when considering that Europe had strong historical connections with Ghana; the country was part of the British Empire from 1878 to 1958. It is therefore surprising that species from other non-tropical continents, such as temperate Asia and North America, have a much higher representation in the alien flora of Ghana than those from Europe. Thus, while climatic mismatch is a strongly limiting factor for alien species exchange (Seebens et al. 2015; Mayer et al. 2017; Haeuser et al. 2018) and arguably might contribute to the low representation of European plants, other factors that warrant further investigation are most likely involved as well. Similarly, the modest contribution of species that are native to other parts of Africa contradicts the fact that intracontinental exchange of alien plants plays an important role in forming national alien floras all over the world (van Kleunen et al. 2015). In global terms, the continents that contribute most to the naturalized alien flora of the world are temperate Asia (20.3\%), North America (17.1\%) and 
Fig. 6 a Relationship between the number of naturalized species in a region and its population density (expressed as number of inhabitants per $\mathrm{km}^{2}$ ). The positive relationship, tested by Pearson's product-moment correlation was significant $(\mathrm{t}=4.889, \mathrm{df}=8$

$p$ value $=0.00121)$. After removing the outlier of the Greater Accra, the correlation was not significant anymore $(\mathrm{t}=1.1095$, df 7 , $p$ value $=0.3039$ )

b Relationship between the number of naturalized species in a region and its distance from the sea. The relationship, tested by Pearson's product-moment correlation was marginally significant $(\mathrm{t}=-2.109$, $\mathrm{df}=8, p$ value $=0.0679)$, but became non-significant after removing the outlier of the city of Accra $(\mathrm{t}=$ -1.6408 , df 7 , $p$ value $=0.1449)$
Fig. 7 Relationship between the number of naturalized species in a region and precipitation during the driest period (expressed as the climatic PCA-axis 3 score; see Methods for details). The relationship, tested by Pearson's product-moment correlation was significant $(\mathrm{t}=2.437, \mathrm{df}=8$, $p$ value $=0.0407)$ and remained marginally significant after removing the outlier of Greater Accra $(\mathrm{t}=1.9415, \mathrm{df} 7$, $p$ value $=0.0902)$
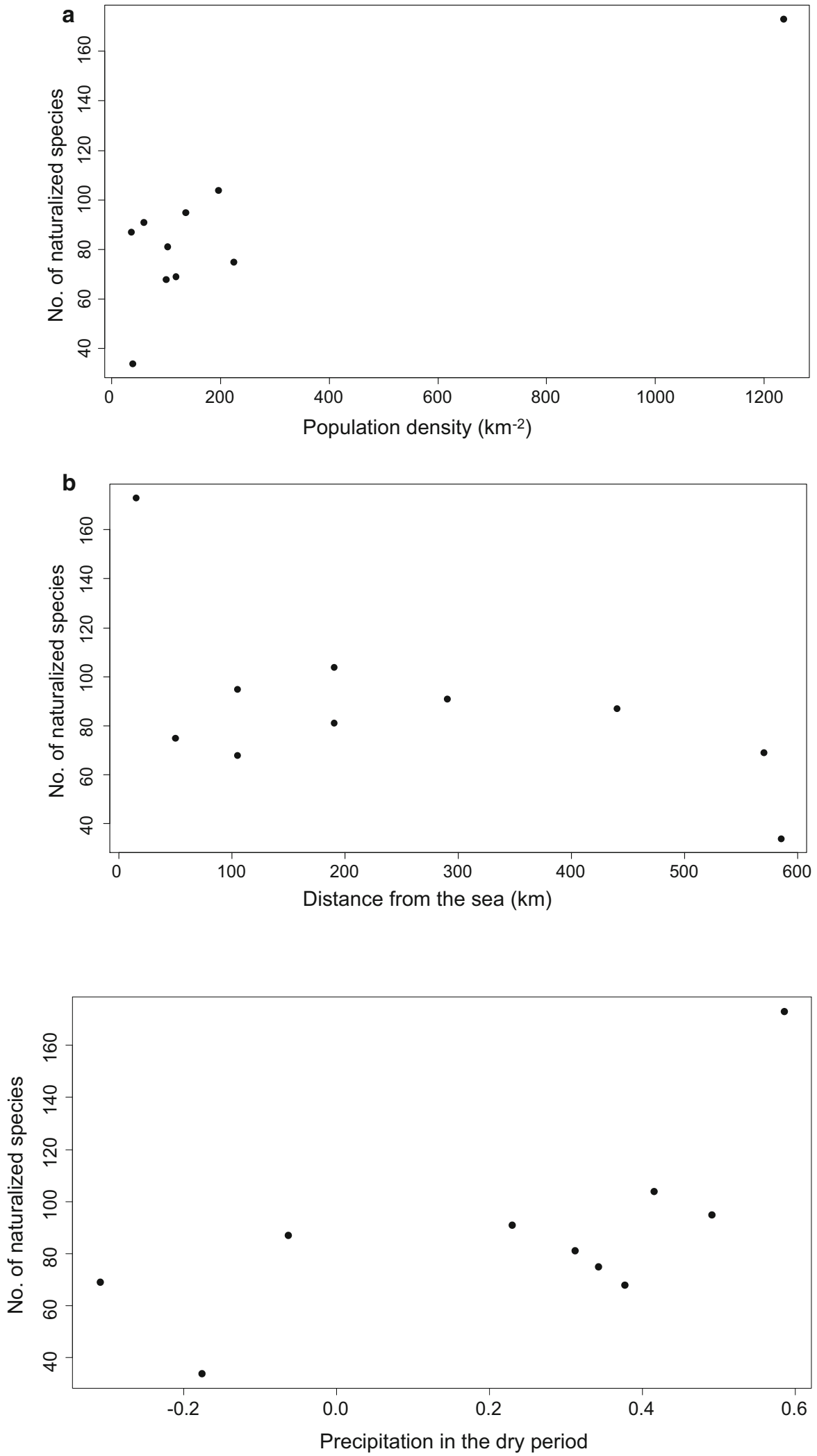
Europe (15.1\%), followed by Africa (14.3\%) and South America (12.8\%; see Pyšek et al. 2017), which is in sharp contrast to the high contribution of prevailing donor regions of the Ghanian naturalized flora, i.e. South America (56\%), North America (44\%) and tropical Asia (34\%; Fig. 3a).

In terms of the regional richness of naturalized species, the increase with human population density is in accord with the generally accepted effect of urbanization on plant invasions (Pyšek 1998; Aronson et al. 2014), and the decrease with distance from the sea confirms the recently reported importance of sea coast areas as hotspots of naturalized alien species (Dawson et al. 2017). In our study, however, these patterns were largely driven by Greater Accra, the region richest in naturalized species in Ghana. This region harbours the city of Accra, has a high population density and its port serves as an entry point of alien species into the country. The only factor whose effect remained significant with the outlier represented by the city of Accra removed was precipitation in the dry season. Regions that receive more precipitation in this period are more favourable for naturalization of alien plants (see e.g. Lambdon et al. 2008; Inderjit et al. 2018).

\section{Conclusions}

The alien flora of Ghana is one of the first nation-wide inventories for a tropical African country that has been compiled using standardized criteria (Richardson et al. 2000; Blackburn et al. 2011). As such, we believe that this case study could serve as a stimulus for other countries in hitherto understudied tropical regions, for which basic data on the alien flora is still often incomplete. Such inventories are useful for a variety of purposes beyond primary research, such as for land management decisions, and guiding nature conservation policies. In particular, they are crucial for assessing the impacts of invasive species on the environment and human livelihoods (Latombe et al. 2017; Bacher et al. 2018). In terms of the knowledge of the alien flora of Ghana, our study can trigger additional research within this country, as for some of the naturalized species, among them the five that are considered invasive, precise spatial information about their distribution is still lacking.
Acknowledgements The authors would like to thank colleagues at Forest Research Institute of Ghana, Kwame Nkrumah University of Science and Technology, Friends of the Earth, Resource Trust, and Forest Services Department of Ghana whose feedback helped improved the manuscript. MA was supported by KNUST Research Fund, PP and JP were supported by project no. 14-36079G Centre of Excellence PLADIAS (Czech Science Foundation) and long-term research development project RVO 67985939 (The Czech Academy of Sciences). FE was supported by the Austrian Science Foundation FWF (Grant I2086-B16), and MvK by the German Research Foundation DFG (Grant 264740629). We thank Zuzana Sixtová for technical assistance. We appreciate the comments of three anonymous reviewers on the previous version of the manuscript.

\section{References}

African Plants Database (2012) Conservatoire et Jardin botaniques de la Ville de Genève and South African National Biodiversity Institute, Pretoria. http://www.ville-ge.ch/ musinfo/bd/cjb/africa. Accessed Aug 2017

Aronson MFJ, La Sorte FA, Nilon CH, Katti M, Goddard MA, Lepczyk CA, Warren PS, Williams NSG, Cilliers S, Clarkson B, Dobbs C, Dolan R, Hedblom M, Klotz S, Louwe Koojimans J, Kühn I, MacGregor-Fors I, McDonnell M, Mörtberg U, Pyšek P, Siebert S, Sushinsky J, Werner P, Winter M (2014) A global analysis of the impacts of urbanization on bird and plant diversity reveals key anthropogenic drivers. Proc R Soc B 281:20133330. https://doi.org/10.1098/rspb.2013.3330

Bacher S, Blackburn TM, Essl F, Jeschke JM, Genovesi P, Heikkilä J, Jones G, Keller R, Kenis M, Kueffer C, Martinou AF, Nentwig W, Pergl J, Pyšek P, Rabitsch W, Richardson DM, Roy HE, Saul W-C, Scalera R, Vilà M, Wilson JRU, Kumschick S (2018) Socio-economic impact classification of alien taxa (SEICAT). Methods Ecol Evol 9:159-168. https://doi.org/10.1111/2041-210X.12844

Blackburn TM, Pyšek P, Bacher S, Carlton JT, Duncan RP, Jarošík V, Wilson JRU, Richardson DM (2011) A proposed unified framework for biological invasions. Trends Ecol Evol 26:333-339. https://doi.org/10.1016/j.tree.2011.03. 023

Blackburn TM, Essl F, Evans T, Hulme PE, Jeschke JM, Kühn I, Kumschick S, Marková Z, Mrugała A, Nentwig W, Pergl J, Pyšek P, Rabitsch W, Ricciardi A, Richardson DM, Sendek A, Vilà M, Wilson JRU, Winter M, Genovesi P, Bacher S (2014) A unified classification of alien species based on the magnitude of their environmental impacts. PLoS Biol 12:e1001850. https://doi.org/10.1371/journal.pbio. 1001850

Breiman L, Friedman JH, Olshen RA, Stone CG (1984) Classification and regression trees. Wadsworth International Group, Belmont

Brummit RK (2001) World geographical scheme for recording plant distributions, 2nd edn. Hunt Institute for Botanical Documentation, Pittsburgh

CABI (2014) Invasive species compendium. CAB International, Wallingford. www.cabi.org/isc. Accessed Aug 2017 
Cayuela L, Stein A, Oksanen J (2017) Taxonstand: taxonomic standardization of plant species names. R package version 2.0. R Foundation for Statistical Computing. https:// CRAN.R-project.org/package $=$ Taxonstand

CBD (2000) Alien species that threaten ecosystems, habitats or species. UNEP/CBD/COP/5/8. Secretariat of the Convention on Biological Diversity, Nairobi

Crawley MJ (2007) R book. Wiley, Chichester

Dawson W, Mndolwa AS, Burslem DFRP, Hulme PE (2008) Assessing the risks of plant invasions arising from collections in tropical botanical gardens. Biodivers Conserv 17:1979-1995. https://doi.org/10.1007/s10531-008-9345-0

Dawson W, Moser D, van Kleunen M, Kreft H, Pergl J, Pyšek P, Weigelt P, Winter M, Lenzner B, Blackburn TM, Dyer EE, Cassey P, Scrivens SL, Economo EP, Guénard B, Capinha C, Seebens H, García-Díaz P, Nentwig W, García-Berthou E, Casal C, Mandrak NE, Fuller P, Meyer C, Essl F (2017) Global hotspots and correlates of alien species richness across taxonomic groups. Nat Ecol Evol 1:0186. https:// doi.org/10.1038/s41559-017-0186

De'ath G, Fabricius KE (2000) Classification and regression trees: a powerful yet simple technique for ecological data analysis. Ecology 81:3178-3192

Dullinger I, Wessely J, Bossdorf O, Dawson W, Essl F, Gattringer A, Klonner G, Kreft H, Kuttner M, Moser D, Pergl J, Pyšek P, Thuiller W, van Kleunen M, Weigelt P, Winter M, Dullinger S (2017) Climate change will increase the naturalization risk from garden plants in Europe. Glob Ecol Biogeogr 26:43-53. https://doi.org/10.1111/geb.12512

Dupin M, Reynaud P, Jarošík V, Baker R, Brunel S, Eyre D, Pergl J, Makowski D (2011) Effects of the training dataset characteristics on the performance of nine species distribution models: application to Diabrotica virgifera virgifera. PLoS ONE 6:e20957. https://doi.org/10.1371/ journal.pone.0020957

Dyer E, Cassey P, Redding DW, Collen B, Franks V, Gaston KJ, Jones KE, Kark S, Orme CDL, Blackburn TM (2017) The global distribution and drivers of alien bird species richness. PLoS Biol 15:e2000942

Essl F, Bacher S, Genovesi P, Hulme PE, Jeschke JM, Katsanevakis S, Kowarik I, Kühn I, Pyšek P, Rabitsch W, Schindler S, van Kleunen M, Vilà M, Wilson JRU, Richardson DM (2018) Which taxa are alien? Criteria, applications, and uncertainties. BioScience 68:496-509. https://doi.org/10.1093/biosci/biy057

GBIF (2017) Occurrence download. https://www.gbif.org/ occurrence/search?q=plants $\% 20$ ghana\&country= GH\&advan. Global Biodiversity Information Facility, Copenhagen. Accessed Aug 2017

Ghana Statistical Service (GSS) (2012) 2010 Population and housing census final results. http://www.statsghana.gov. gh/docfiles/2010phc/2010_POPULATION_AND HOUSING_CENSUS_FINAL_RESULTS.pdf. Accessed 2 Jan 2018

Government of Ghana (2015) Ghana national spatial development framework 2015-2035. Volume I: conditions and main issues. http://www.ghanalap.gov.gh/files/NSDFFinal-Report-Vol-I-Final-Edition-TAC.pdf. Accessed 2 Jan 2018

Haeuser E, Dawson W, Thuiller W, Dullinger S, Block S, Bossdorf O, Carboni M, Conti L, Dullinger I, Essl F,
Klonner G, Moser D, Münkemüller T, Parepa M, Talluto MV, Kreft H, Pergl J, Pyšek P, Weigelt P, Winter M, Hermy M, Van der Veken S, Roquet C, van Kleunen M (2018) The European ornamental garden flora as an invasion debt under climate change. J Appl Ecol. 55:2386-2395. https://doi.org/10.1111/1365-2664.13197

Herron PM, Martine CT, Latimer AM, Leicht-Young SA (2007) Invasive plants and their ecological strategies: prediction and explanation of woody plant invasions in New England. Divers Distrib 13:633-644. https://doi.org/10.1111/j.14724642.2007.00381.x

Inderjit, Pergl J, van Kleunen M, Hejda M, Babu CR, Majumdar S, Singh P, Singh SP, Salamma S, Rao BRP, Pyšek P (2018) Naturalized alien flora of the Indian states: biogeographic patterns, taxonomic structure and drivers of species richness. Biol Invasions. 20:1625-1638. https:// doi.org/10.1007/s10530-017-1622-y

Issaka NR, Mohammed M, Tobita S, Nakamura S, Owusu-Adjei E (2012) Indigenous fertilizing materials to enhance soil productivity in Ghana. In: Whalen KJ (ed) Soil fertility improvement and integrated nutrient management-a global perspective. InTechOpen, London, pp 119-134

Jeschke J, Pyšek P (2018) Tens rule. In: Jeschke J, Heger T (eds) Invasion biology: hypotheses and evidence. CAB International, Wallingford, pp 124-132

Kalusová V, Chytrý M, van Kleunen M, Mucina L, Dawson W, Essl F, Kreft H, Pergl J, Weigelt P, Winter M, Pyšek P (2017) Naturalization of European plants on other continents: the role of donor habitats. Proc Natl Acad Sci USA 114:13756-13761. https://doi.org/10.1073/pnas.1705487 114

Křivánek M, Pyšek P (2006) Predicting invasions by woody species in a temperate zone: a test of three risk assessment schemes in the Czech Republic (Central Europe). Divers Distrib 12:319-327. https://doi.org/10.1111/j.1366-9516. 2006.00249.x

Lambdon PW, Pyšek P, Basnou C, Hejda M, Arianoutsou M, Essl F, Jarošík V, Pergl J, Winter M, Anastasiu P, Andriopoulos P, Bazos I, Brundu G, Celesti-Grapow L, Chassot P, Delipetrou P, Josefsson M, Kark S, Klotz S, Kokkoris Y, Kühn I, Marchante H, Perglová I, Pino J, Vilà M, Zikos A, Roy D, Hulme PE (2008) Alien flora of Europe: species diversity, temporal trends, geographical patterns and research needs. Preslia 80:101-149

Latombe G, Pyšek P, Jeschke JM, Blackburn TM, Bacher S, Capinha C, Costello MJ, Fernández M, Gregory RD, Hobern D, Hui C, Jetz W, Kumschick S, McGrannachan C, Pergl J, Roy HE, Scalera R, Squires ZE, Wilson JRU, Winter M, Genovesi P, McGeoch MA (2017) A vision for global monitoring of biological invasions. Biol Conserv 213:295-308. https://doi.org/10.1016/j.biocon.2016.06.013

Lewis SL, Maslin MA (2015) Defining the Anthropocene. Nature 519:171-180

Mayer K, Haeuser E, Dawson W, Essl F, Kreft H, Pergl J, Pyšek P, Weigelt P, Winter M, Lenzner B, van Kleunen M (2017) Current and future local naturalization potential of ornamental species planted in urban green spaces and private gardens. Biol Invasions 19:3613-3627. https://doi.org/10. 1007/s10530-017-1594-y

McDonnell T (2018) What's the world's fastest-growing economy? Ghana contends for the Crown. The New York 
Times. https://www.nytimes.com/2018/03/10/world/africa/ ghana-worlds-fastest-growing-economy.html. Accessed 2 Apr 2018

Meyer C, Kreft H, Guralnick RP, Jetz W (2015) Global priorities for an effective information basis of biodiversity distributions. Nat Commun 6:8221. https://doi.org/10.1038/ ncomms 9221

Meyer C, Weigelt P, Kreft H (2016) Multidimensional biases, gaps and uncertainties in global plant occurrence information. Ecol Lett 19:992-1006. https://doi.org/10.1111/ ele. 12624

Milbau A, Stout JC (2008) Factors associated with alien plants transitioning from casual, to naturalized, to invasive. Conserv Biol 22:308-317. https://doi.org/10.1111/j.15231739.2007.00877.x

Pagad S, Genovesi P, Carenevali L, Schigel D, McGeoch M (2018) Introduding the global register of introduced and invasive species. Sci Data 5:170202. https://doi.org/10. 1038/sdata.2017.202

Pyšek P (1998) Alien and native species in Central European urban floras: a quantitative comparison. J Biogeogr 25:155-163

Pyšek P, Richardson DM, Rejmánek M, Webster G, Williamson M, Kirschner J (2004) Alien plants in checklists and floras: towards better communication between taxonomists and ecologists. Taxon 53:131-143

Pyšek P, Jarošík V, Hulme PE, Kühn I, Wild J, Arianoutsou M, Bacher S, Chiron F, Didžiulis V, Essl F, Genovesi P, Gherardi F, Hejda M, Kark S, Lambdon PW, DesprezLoustau A-M, Nentwig W, Pergl J, Poboljšaj K, Rabitsch W, Roques A, Roy DB, Shirley S, Solarz W, Vilà M, Winter M (2010) Disentangling the role of environmental and human pressures on biological invasions across Europe. Proc Natl Acad Sci USA 107:12157-12162. https:// doi.org/10.1073/pnas.1002314107

Pyšek P, Jarošík V, Hulme PE, Pergl J, Hejda M, Schaffner U, Vilà M (2012) A global assessment of invasive plant impacts on resident species, communities and ecosystems: the interaction of impact measures, invading species' traits and environment. Glob Change Biol 18:1725-1737. https://doi.org/10.1111/j.1365-2486.2011.02636.x

Pyšek P, Pergl J, Essl F, Lenzner B, Dawson W, Kreft H, Weigelt P, Winter M, Kartesz J, Nishino M, Antonova LA, Barcelona JF, Cabezas FJ, Cárdenas D, Cárdenas-Toro J, Castaño N, Chacón E, Chatelain C, Dullinger S, Ebel AL, Figueiredo E, Fuentes N, Genovesi P, Groom QJ, Henderson L, Inderjit Kupriyanov A, Masciadri S, Maurel N, Meerman J, Morozova O, Moser D, Nickrent D, Nowak PM, Pagad S, Patzelt A, Pelser PB, Schulze M, Seebens H, Shu W, Thomas J, Velayos M, Weber E, Wieringa JJ, Baptiste MP, van Kleunen M (2017) Naturalized and invasive flora of the world: species diversity, taxonomic and phylogenetic patterns, geographic distribution and global hotspots of plant invasion. Preslia 89:203-274. https://doi.org/10.23855/preslia.2017.203

Pyšek P, Meyerson LA, Simberloff D (2018) Introducing “Alien Floras and Faunas", a new series in Biological Invasions. Biol Invasion. https://doi.org/10.1007/s10530-017-1648-1

R Core Development Team (2014) R: a language and environment for statistical computing, version 3.0.2. R Foundation for Statistical Computing, Vienna
Randall RP (2017) A global compendium of weeds, 3rd edn. R. P. Randall Publ., Mount Helena

Razanajatovo M, Maurel N, Dawson W, Essl F, Kreft H, Pergl J, Pyšek P, Weigelt P, Winter M, van Kleunen M (2016) Plants capable of selfing are more likely to become naturalized. Nat Commun 7:13313. https://doi.org/10.1038/ ncomms 13313

Reichard SH, Hamilton CW (1997) Predicting invasions of woody plants introduced into North America. Conserv Biol 11:193-203

Richardson DM (ed) (2011) Fifty years of invasion ecology: the legacy of Charles Elton. Blackwell Publishing, Oxford

Richardson DM, Pyšek P (2006) Plant invasions: merging the concepts of species invasiveness and community invasibility. Progr Phys Geogr 30:409-431. https://doi.org/10. 1191/0309133306pp490pr

Richardson DM, Pyšek P, Rejmánek M, Barbour MG, Panetta FD, West CJ (2000) Naturalization and invasion of alien plants: concepts and definitions. Divers Distrib 6:93-107

Seebens H, Essl F, Dawson W, Fuentes N, Moser D, Pergl J, Pyšek P, van Kleunen M, Weber E, Winter M, Blasius B (2015) Global trade will accelerate plant invasions in emerging economies under climate change. Glob Change Biol 21:4128-4140. https://doi.org/10.1111/gcb.13021

Seebens H, Blackburn TM, Dyer EE, Genovesi P, Hulme PE, Jeschke JM, Pagad S, Pyšek P, Winter M, Arianoutsou M, Bacher S, Blasius B, Brundu G, Capinha C, Celesti-Grapow L, Dawson W, Dullinger S, Fuentes N, Jäger H, Kartesz J, Kenis M, Kreft H, Kühn I, Lenzner B, Liebhold A, Mosena A, Moser D, Nishino M, Pearman D, Pergl J, Rabitsch W, Rojas-Sandoval J, Roques A, Rorke S, Rossinelli S, Roy HE, Scalera R, Schindler S, Štajerová K, Tokarska-Guzik B, van Kleunen M, Walker K, Weigelt P, Yamanaka T, Essl F (2017) No saturation in the accumulation of alien species worldwide. Nat Commun 8:14435. https://doi.org/10.1038/ncomms14435

Seebens H, Blackburn TM, Dyer EE, Genovesi P, Hulme PE, Jeschke JM, Pagad S, Pyšek P, Winter M, Arianoutsou M, Bacher S, Brundu G, Capinha C, Celesti-Grapow L, Dawson W, Dullinger S, Fuentes N, Jäger H, Kartesz J, Kenis M, Kühn I, Liebhold A, Mosena A, Nishino M, Pearman D, Pergl J, Rabitsch W, Rojas-Sandoval J, Roques A, Rorke S, Rossinelli S, Roy HE, Scalera R, Schindler S, Štajerová K, Tokarska-Guzik B, van Kleunen M, Walker K, Yamanaka T, Essl F (2018) Global rise in emerging alien species results from accessibility of new source pools. Proc Natl Acad Sci USA 115:E2264-E2273. https://doi. org/10.1073/pnas.1719429115

Steffen W, Grinevald J, Crutzen P, McNeill P (2011) The Anthropocene: conceptual and historical perspectives. Philos Trans R Soc A 369:842-867

Steinberg G, Colla P (1995) CART: tree-structured nonparametric data analysis. Salford Systems, San Diego

United Nations (2017) World population prospects: the 2017 revision, Volume I: Comprehensive Tables. United Nations Department of Economic and Social Affairs, Population Division, New York. https://esa.un.org/unpd/ wpp/Publications/Files/WPP2017_Volume-I_ Comprehensive-Tables.pdf. Accessed 24 Apr 2018

van Kleunen M, Dawson W, Essl F, Pergl J, Winter M, Weber E, Kreft H, Weigelt P, Kartesz J, Nishino M, Antonova LA, 
Barcelona JF, Cabezas FJ, Cárdenas D, Cárdenas-Toro J, Castaño N, Chacón E, Chatelain C, Ebel AL, Figueiredo E, Fuentes N, Groom QJ, Henderson L, Inderjit Kupriyanov A, Masciadri S, Meerman J, Morozova O, Moser D, Nickrent DL, Patzelt A, Pelser PB, Baptiste MP, Poopath M, Schulze M, Seebens H, Shu W, Thomas J, Velayos M, Wieringa JJ, Pyšek P (2015) Global exchange and accumulation of non-native plants. Nature 525:100-103. https://doi.org/10.1038/nature14910

van Kleunen M, Pyšek P, Dawson W, Essl F, Kreft H, Pergl J, Weigelt P, Stein A, Dullinger S, König C, Lenzner B, Maurel N, Moser D, Seebens H, Kartesz J, Nishino M, Aleksanyan A, Ansong M, Antonova LA, Barcelona JF, Breckle SW, Brundu G, Cabezas FJ, Cárdenas D, Cárdenas-Toro J, Castano N, Chacón E, Chatelain C, Conn B, de Sá Dechoum M, Dufour-Dror JM, Ebel AL, Figueiredo E, Fragman-Sapir O, Fuentes N, Groom QJ, Henderson L, Inderjit, Jogan N, Krestov P, Kupriyanov A, Masciadri S, Meerman J, Morozova O, Nickrent D, Nowak A, Patzelt A, Pelser PB, Shu WS, Thomas J, Uludag A, Velayos M,
Verkhosina A, Villasenor JL, Weber E, Wieringa JJ, Yazlik A, Zeddam A, Zykova E, Winter M (2018) The Global Naturalized Alien Flora (GloNAF) database. Ecology. https://doi.org/10.1002/ecy.2542

Vilà M, Espinar JL, Hejda M, Hulme PE, Jarošík V, Maron JL, Pergl J, Schaffner U, Sun Y, Pyšek P (2011) Ecological impacts of invasive alien plants: a meta-analysis of their effects on species, communities and ecosystems. Ecol Lett 14:702-708. https://doi.org/10.1111/j.1461-0248.2011. 01628.X

Vinogradova Y, Pergl J, Hejda M, Essl F, van Kleunen M, REGIONAL CONTRIBUTORS, Pyšek P (2018) Naturalized alien plants of Russia: insights from regional inventories. Biol Invasions. https://doi.org/10.1007/s10530-0181686-3

Vitousek PM, D'Antonio CM, Loope LL, Rejmánek M, Westbrooks R (1997) Introduced species: a significant component of human-caused global change. NZ J Ecol 21:1-16

Williamson M, Fitter A (1996) The varying success of invaders. Ecology 77:1661-1666 